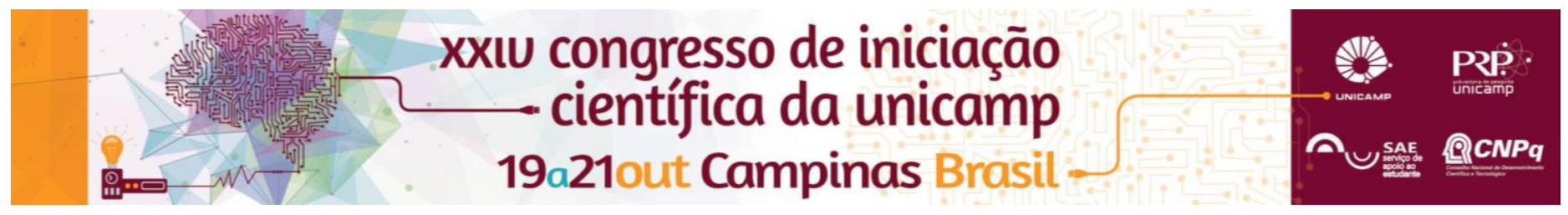

\title{
Metodologia utilizada pelos treinadores para o ensino do handebol na categoria infantil: uma reflexão a partir do ensino dos jogos esportivos coletivos
}

\author{
João P. T. Di Gilio*, Sérgio Settani Giglio.
}

\begin{abstract}
Resumo
Com a expansão do handebol no cenário nacional o presente estudo teve como objetivo identificar e analisar as metodologias que o treinador de um time de handebol da categoria infantil (12 a 14 anos) utiliza. Foram entrevistados quatro treinadores da categoria, por meio de uma entrevista semiestruturada, identificando que não há um consenso entre eles acerca das metodologias utilizadas. Os professores que apontam maior influência da graduação em Educação Física no seu trabalho utilizam de metodologias mais globais de ensino. Já os treinadores que apontam uma maior influência do seu período como atleta utilizam de metodologias mais fechadas.
\end{abstract}

Palavras-chave: Handebol; Pedagogia do Esporte; Esporte Coletivo.

\section{Introdução}

Ao se pensar em uma pedagogia dos esportes coletivos pode-se classificar o handebol como um jogo desportivo coletivo (JDC) (GARGANTA, 1995). A fim de auxiliar no debate da pedagogia dos esportes coletivos, Bayer (1994) explica que todos os esportes coletivos partem dos mesmos princípios operacionais, possibilitando um ensino com características comuns entre eles. Devido aos diversos métodos encontrados na pedagogia dos esportes coletivos, como apontado por Garganta (1995), torna-se necessário identificar os métodos utilizados, principalmente nas categorias menores. Temos como foco do estudo a categoria infantil por ser a última categoria da chamada "iniciação esportiva". O presente trabalho teve como objetivo principal identificar e caracterizar os critérios que o professor/treinador de um time de handebol infantil utiliza para definir suas aulas, partindo do ponto de vista da metodologia de ensino, verificando o embasamento que o levou a escolher esses métodos e o que influenciou nessas escolhas. Sendo assim, estrevistamos quatro treinadores de equipes de handebol da categoria infantil situadas no interior paulista. Os indivíduos que participaram receberam uma identificação que segue a ordem numeral de 1 (um) a 4 (quatro) - entrevistada 1 (E1), entrevistado 2 (E2), entrevistado 3 (E3) e entrevistado 4 (E4) - para manter o sigilo que uma pesquisa científica requer.

\section{Resultados e Discussão}

Foi possível identificar, no discurso de um dos treinadores (E2), que sua metodologia é pautada em um ensino que se baseia nas unidades funcionais, aproximando-se do método situacional (GARGANTA, 1995), passando também pelo global-funcional, ao passar de jogos mais simples aos mais complexos (GARGANTA, 1995). Já nas palavras da E1 é apresentado que, nos seus treinos, os conteúdos são transferidos aos alunos passando por todas as metodologias apresentadas anteriormente, globalfuncional, analítico-sintético e o situacional (GARGANTA, 1995), levando em consideração o nível de jogo apresentado pelos alunos.

Os entrevistados E1, E3 e E4 destacaram na maioria de suas falas uma grande necessidade de se trabalhar os fundamentos (técnicas) nessa categoria, apontando que o jogo não desenvolve sem o domínio deles. Além disso, E3 e E4 relataram em suas falas uma carga grande de trabalho desse fragmento do jogo em seus treinos, apontando, também, que trouxeram isso, mesmo que pouco, dos seus treinadores quando atletas. Com isso, pode-se observar que em grande parte dos seus trabalhos E3 e E4 utilizam do método analítico-sintético, centrando a aprendizagem do aluno na técnica (o que fazer) desvinculada da tática (como fazer), focando o ensino nas repetições e automatização de movimentos (GARGANTA, 1995).

Em suas falas, os treinadores afirmaram necessário desenvolver 0 individual de cada atleta, passando, necessariamente, por situações de um contra zero (1x0), um contra um (1x1), e assim por diante chegando até em uma situação de três contra três $(3 \times 3)$. Destacando esses níveis de relação que os atletas tem que dominar, entendendo que o jogo formal $(7 \times 7)$ é de extrema complexidade para compreensão total nessa idade.

Os entrevistados que mais expressaram influências de seus antigos treinadores utilizarem de metodologias semelhantes de abordar o mesmo conteúdo. Já os treinadores que afirmaram ter maior influência do período da graduação na elaboração de seus treinos caracterizam seus treinos de forma mais geral, informando sobre diversos conceitos técnico-táticos no discurso.

\section{Conclusões}

Com os resultados das entrevistas conclui-se que há disparidades nas metodologias utilizadas pelos treinadores nas categorias infantis. Dois treinadores utilizam predominantemente metodologias mais globais de ensino, sem fragmentar elementos do jogo, apontando maior influência do período da graduação na construção de seus trabalhos. Já os outros dois treinadores frequentemente utilizam métodos em que se extraem elementos do jogo de seu contexto, destacando o período em que foram atletas da modalidade como fundamental na elaboração de seus treinos.

\section{Agradecimentos}

Agradeço ao CNPq pelo financiamento da pesquisa. Agradeço também ao apoio do meu orientador, do PIBIC/UNICAMP e da FEF/UNICAMP.

BAYER, C. O ensino dos desportos colectivos. Lisboa: Dinalivros, 1994. GARGANTA, J. Para uma teoria dos jogos desportivos colectivos. In: A. Graça \& J. Oliveira (Eds.). O ensino dos jogos desportivos. Porto: Universidade do Porto, 1995 